\title{
Metagenomic analysis of the uterine bacterial microbiota in healthy and metritic postpartum dairy cows
}

\author{
T. M. A. Santos, ${ }^{*}$ R. O. Gilbert, $†$ and R. C. Bicalho* \\ *Department of Population Medicine and Diagnostic Sciences, and \\ †Department of Clinical Sciences, College of Veterinary Medicine, Cornell University, Ithaca, NY 14853
}

\begin{abstract}
At present, many bacterial species are validly known as etiological agents of dairy cattle metritis, yet the vast uncultured fraction has received no attention so far. The purpose of this study was to use culture-independent methods to describe and compare the uterine bacterial composition in healthy and metritic postpartum Holstein dairy cows. Both group-specific $16 \mathrm{~S}$ ribosomal DNA PCR-denaturing gradient gel electrophoresis (DGGE) and clone library sequencing of broad-range $16 \mathrm{~S}$ ribosomal DNA PCR revealed differences in the bacterial communities comparing healthy and metritic cows. Bacterial diversity in healthy and metritic uteri was greater and more complex than described previously by traditional culture methods. Sequences were assigned to 5 major groups (Gammaproteobacteria, Firmicutes, Fusobacteria, Bacteroidetes, and Tenericutes) and to uncultured bacteria. Additionally, DGGE suggested the presence of Actinobacteria. Most clone sequences in the metritic status libraries were affiliated with the phylum Fusobacteria. Many components, especially from other phyla, have not previously been isolated from cases of metritis. In the clone libraries from the healthy status dairy cows, Gammaproteobacteria was the most prominent group and most sequences showed high identity with Mannheimia varigena, Pasteurella hemolytica, and members of the phylum Tenericutes. Our data showed that the uterine bacterial community in postpartum dairy cows differed considerably between healthy and metritic cows and described the occurrence of a previously unrecognized extent of this diversity in the bovine intrauterine microbiota.
\end{abstract}

Key words: 16S ribosomal RNA clone library, bacterial diversity, dairy cow, metritis

\section{INTRODUCTION}

Metritis is one of the most important reproductive disorders in cattle and results from uterine contamina-

Received July 30, 2010.

Accepted September 19, 2010.

${ }^{1}$ Corresponding author: rcb28@cornell.edu tion with bacteria following parturition (Dohmen et al., 2000; Azawi, 2008). Escherichia coli and Arcanobacterium pyogenes are traditionally considered the most relevant species involved in the pathogenesis of metritis because of their persistence in the contaminated uterus (Sheldon et al., 2002; Williams et al., 2005; Miller et al., 2007; Sheldon et al., 2010). However, numerous other pathogenic microorganisms, such as Fusobacterium necrophorum, Prevotella melaninogenicus, Bacteroidetes spp., Pseudomonas spp., Streptococcus spp., and Staphylococcus spp., in a variety of combinations, have been isolated from infected uteri of metritic cows and are thought to be responsible for puerperal metritis (Williams et al., 2005; Azawi, 2008).

Classically, characterization of the pathogenic uterine microbiota in bovine has relied on cultivation of uterine secretions. Although we recognize the value of pathogen culturing, previous studies might have underestimated the microbial complexity of the intrauterine environment of postpartum cows, given that less than $1 \%$ of the microorganisms in many environments are readily cultured under standard laboratory conditions (Amann et al., 1995; Whitman et al., 1998). In face of the intrinsic limitations associated with traditional culture methods, culture-independent methods, as proposed by metagenomics (Rondon et al., 2000; Handelsman, 2004), are now fundamental in studying and understanding the physiology, genetics, and community ecology structure of the "unseen majority."

Although the uterine microbial composition has been exhaustively studied based on traditional culture, no culture-independent methods have yet been conducted. In this study, we present a descriptive comparative analysis of the bacterial assemblage of the intrauterine environment of postpartum dairy cows and investigate whether major differences exist between puerperal metritic and healthy cows.

\section{MATERIALS AND METHODS}

\section{Uterine Fluid Sampling}

Intrauterine fluid was sampled from 20 Holstein dairy cows between November 2009 and December 2009 
from 2 commercial dairy farms near Ithaca, New York. Of these, 5 healthy postpartum cows and 5 cows with diagnosed puerperal metritis from each dairy farm had uterine fluid collected by using a flushing technique aided by a Foley catheter. Briefly, a Foley catheter was manipulated through the cervix and the catheter's cuff was inflated and immediately passed through the cervix. Then, $1 \mathrm{~L}$ of sterile saline was fluxed into the uterus and around $0.5 \mathrm{~L}$ was recovered into a sterile glass container. The samples were maintained at $4^{\circ} \mathrm{C}$ during transportation until processing. Puerperal metritis was clinically defined as an abnormally enlarged uterus and a fetid, watery, red-brown uterine discharge, with signs of systemic illness (decreased milk yield, dullness, or other signs of toxemia) and fever $\left(>39.5^{\circ} \mathrm{C}\right)$ within 21 d after parturition (Sheldon et al., 2006). Healthy cows were detected by the absence of fetid, watery, red-brown uterine discharge and other metritis signs as described by Sheldon et al. (2006).

\section{DNA Extraction from Uterine Fluid}

Samples were mixed to disperse any solid tissue or mucus. Approximately $250 \mathrm{~mL}$ of uterine fluid from each cow with the same health status and from the same dairy farm was filtered in sterile gauze and pooled to compose 4 mixed samples. Approximately $30 \mathrm{~mL}$ of the pooled sample was centrifuged for $30 \mathrm{~min}$ at 15,000 $\times g$ at $4^{\circ} \mathrm{C}$. The supernatant was discarded and the pellet was resuspended in $2 \mathrm{~mL}$ of $1 \times$ PBS buffer $(137$ $\mathrm{m} M \mathrm{NaCl}, 2.7 \mathrm{~m} M \mathrm{KCl}, 4.3 \mathrm{~m} M \mathrm{Na}_{2} \mathrm{HPO}_{4}, 1.47 \mathrm{~m} M$ $\mathrm{KH}_{2} \mathrm{PO}_{4}, \mathrm{pH}$ 7.4). Isolation of total metagenomic DNA was performed from $400 \mu \mathrm{L}$ of the suspension by using a QIAamp DNA minikit (Qiagen, Santa Clara, CA) according to the manufacturer's instructions for DNA purification from blood or body fluids. Some convenient modifications, such as addition of $400 \mu \mathrm{g}$ of lysozyme and incubation for $12 \mathrm{~h}$ at $56^{\circ} \mathrm{C}$, were included to maximize bacterial DNA extraction. Total DNA was eluted in $50 \mu \mathrm{L}$ of sterile DNase/RNase-free water (Promega, Madison, WI). The DNA concentration and purity were evaluated by optical density using the NanoDrop ND-1000 spectrophotometer (NanoDrop Technologies, Rockland, DE) at wavelengths of 230, 260, and $280 \mathrm{~nm}$. The integrity was assessed through a $0.8 \%$ (wt/vol) agarose gel electrophoresis, stained with $0.5 \mu \mathrm{g} / \mathrm{mL}$ ethidium bromide, and visualized with the MiniBIS Pro (DNR Bio-Imaging System Ltd., Jerusalem, Israel).

\section{Bacterial Community Profiling by Denaturing Gradient Gel Electrophoresis}

An indirect strategy was used to study natural bacterial community profile by denaturing gradient gel elec- trophoresis (DGGE). We used group-specific primers (Table 1) for selective amplification of $16 \mathrm{~S}$ rRNA gene sequences of Alphaproteobacteria, Betaproteobacteria, Gammaproteobacteria, Firmicutes, high G+C-containing Actinobacteria, Bacteroidetes, and Fusobacteria, which provided group-specific fragments that were used as template for a second PCR (nested PCR) when conserved DGGE universal primers (40-bp GC-clamp incorporated on the forward primer) were used. Additionally, we used one universal primer pair to assess the total bacteria assemblage.

In essence, all group-specific and nested PCR reactions of the 16S rRNA gene fragments for DGGE analysis contained $1 \times$ LongAmp Taq reaction buffer $[60 \mathrm{mM}$ Tris-SO $\mathrm{S}_{4}, \mathrm{pH} 9.0 ; 20 \mathrm{~m} M\left(\mathrm{NH}_{4}\right)_{2} \mathrm{SO}_{4} ; 2 \mathrm{mM} \mathrm{MgSO}_{4}$, $3 \%$ glycerol; $0.06 \%$ Nonidet P-40; $0.05 \%$ Tween-20; New England Biolabs, Ipswich, MA], $0.2 \mathrm{~m} M$ dNTPs, $0.2 \mu M$ forward and reverse primers (Table 1), 2.5 U of LongAmp Taq DNA Polymerase (New England Biolabs), and $20 \mathrm{ng}$ of template DNA. Three replicate PCR reactions were performed from each of the 4 uterine DNA samples. Replicate PCR were pooled and amplicons purified using QIAquick PCR Purification kit (Qiagen). The amplification of total bacterial community was performed by using the primer pair 27F/1518R (Giovannoni, 1991; Table 1). The PCR parameters were initial denaturation for 2 min at $94^{\circ} \mathrm{C}$, followed by 34 cycles of denaturation $\left(94^{\circ} \mathrm{C}\right.$ for $\left.30 \mathrm{~s}\right)$, annealing $\left(58^{\circ} \mathrm{C}\right.$ for $\left.50 \mathrm{~s}\right)$, extension $\left(72^{\circ} \mathrm{C}\right.$ for $\left.1 \mathrm{~min}\right)$, and a final extension at $72^{\circ} \mathrm{C}$ for $7 \mathrm{~min}$.

For amplification of Alphaproteobacteria, Betaproteobacteria, Bacteroidetes, and Fusobacteria 16S rRNA gene fragments, primer combinations were

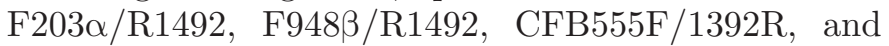
ADF681F/1392R, respectively, and the following cycling parameters (Gomes et al., 2001; Blackwood et al., 2005; Mühling et al., 2008) were used: initial denaturation for $5 \mathrm{~min}$ at $94^{\circ} \mathrm{C}$, followed by 25 cycles of denaturation $\left(94^{\circ} \mathrm{C}\right.$ for $\left.1 \mathrm{~min}\right)$, annealing $\left[56^{\circ} \mathrm{C}\right.$ (Alphaproteobacteria) $/ 61^{\circ} \mathrm{C}$ (Betaproteobacteria and Bacteroidetes) $/ 55.5^{\circ} \mathrm{C}$ (Fusobacteria) for $1 \mathrm{~min}$ ], extension $\left(72^{\circ} \mathrm{C}\right.$ for $2 \mathrm{~min}$ ), and a final extension at $72^{\circ} \mathrm{C}$ for $10 \mathrm{~min}$. For amplification of Gammaproteobacteria $16 \mathrm{~S}$ rRNA gene fragments, the primer combination was $\mathrm{fD} 2 / \mathrm{rP} 1$ and the $\mathrm{PCR}$ conditions (Breitenstein et al., 2001) were initial denaturation for $2 \mathrm{~min}$ at $94^{\circ} \mathrm{C}$, followed by 10 cycles of denaturation $\left(94^{\circ} \mathrm{C}\right.$ for $\left.15 \mathrm{~s}\right)$, annealing $\left(52^{\circ} \mathrm{C}\right.$ for $\left.30 \mathrm{~s}\right)$, extension $\left(72^{\circ} \mathrm{C}\right.$ for $\left.1 \mathrm{~min}\right)$; 20 similar cycles with a 20 -s extension of the elongation phase per cycle; and a final extension at $72^{\circ} \mathrm{C}$ for 2 min. Amplification of the Firmicutes 16S rRNA gene sequences was performed by using the primer system BLS342F/1392R with the following cycling parameters (Blackwood et al., 2005): initial denaturation for $3 \mathrm{~min}$ 


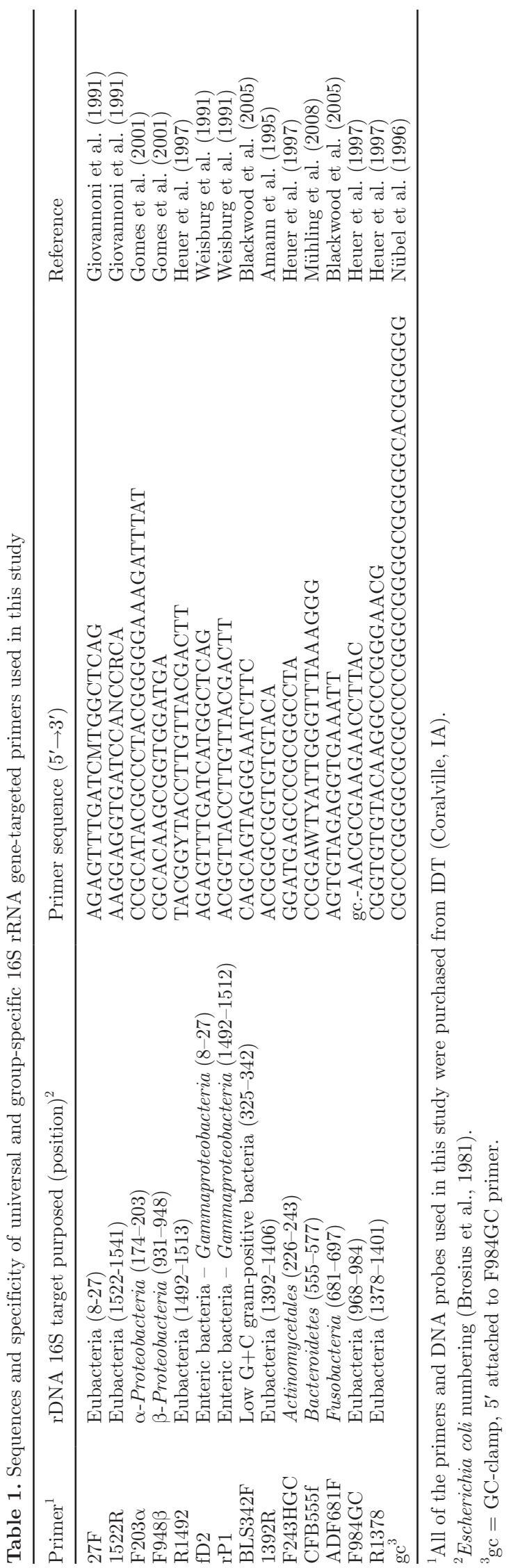

at $95^{\circ} \mathrm{C}$, followed by 35 cycles of denaturation $\left(94^{\circ} \mathrm{C}\right.$ for $30 \mathrm{~s})$, annealing $\left(57^{\circ} \mathrm{C}\right.$ for $\left.30 \mathrm{~s}\right)$, extension $\left(72^{\circ} \mathrm{C}\right.$ for $1.5 \mathrm{~min}$ ), and a final extension at $72^{\circ} \mathrm{C}$ for $7 \mathrm{~min}$. High $\mathrm{G}+\mathrm{C}$-containing Actinobacteria $16 \mathrm{~S}$ rRNA gene fragments were amplified using the combinations of primers 243HGC/1392R with the following cycling parameters (Heuer et al., 1997): initial denaturation for 5 min at $95^{\circ} \mathrm{C}$, followed by 35 cycles of denaturation $\left(94^{\circ} \mathrm{C}\right.$ for 1 min), annealing $\left(63^{\circ} \mathrm{C}\right.$ for $\left.1 \mathrm{~min}\right)$, extension $\left(72^{\circ} \mathrm{C}\right.$ for 2 min), and a final extension at $72^{\circ} \mathrm{C}$ for $10 \mathrm{~min}$.

Group-specific amplicons were used as template in a second round of amplification with a nested bacteria DGGE-PCR universal primer pair (40-bp GC-clamp 5 '-incorporated on the forward primer; Table 1). The cycle protocol for the nested PCR with the primer pairs F984GC/R1378 was (Gelsomino and Cacco, 2006) initial denaturation for $5 \mathrm{~min}$ at $94^{\circ} \mathrm{C}$, followed by 20 cycles of denaturation $\left(94^{\circ} \mathrm{C}\right.$ for $\left.1 \mathrm{~min}\right)$, annealing $\left(53^{\circ} \mathrm{C}\right.$ for 1 min), extension $\left(72^{\circ} \mathrm{C}\right.$ for $\left.2 \mathrm{~min}\right)$, and a final extension at $72^{\circ} \mathrm{C}$ for $10 \mathrm{~min}$. The PCR were performed in a GeneAmp PCR System 9700 (Applied Biosystems, Foster City, CA). Appropriate PCR controls and blanks were included, and products were analyzed by electrophoresis in $1.2 \%$ (wt/vol) agarose gel stained with $0.5 \mu \mathrm{g} / \mathrm{mL}$ ethidium bromide (Sambrook and Russell, 2001) before DGGE analysis.

Profiles of the amplified 16S rRNA gene sequences were produced by DGGE as described by Muyzer et al. (1993) using the DCode Universal Mutation Detection System apparatus (Bio-Rad, Hercules, CA). The PCR products $(\sim 2.5 \mu \mathrm{g})$ were loaded onto an $6 \%$ polyacrylamide (37.5:1 acrylamide: $N, N$ '-methylenebisacrylamide; Sigma-Aldrich, St. Louis, MO) parallel denaturing gradient gel in $1 \times$ Tris-acetate-EDTA buffer [TAE; $40 \mathrm{~m} M$ Tris ( $\mathrm{pH} 8.0), 20 \mathrm{~m} M$ acetic acid, $1 \mathrm{~m} M$ EDTA (pH 8.0)] composed of $0.09 \%$ ( $\mathrm{vol} / \mathrm{vol}$ ) $\mathrm{N}, \mathrm{N}, \mathrm{N}^{\prime}, \mathrm{N}^{\prime}$-tetramethylenediamine (TEMED), and $0.07 \%$ (wt/vol) ammonium persulfate. The denaturing gradient was optimized empirically to 40 to $58 \%$ urea/ formamide $[100 \%$ denaturant contained $7 M$ urea and $40 \%$ (vol/vol) deionized formamide]. The electrophoresis was carried out in $1 \times$ TAE buffer at $50 \mathrm{~V}$ for $16 \mathrm{~h}$ at a constant temperature of $60^{\circ} \mathrm{C}$. The DNA fragments were stained for $20 \mathrm{~min}$ in $1 \times$ TAE buffer with $1 \times$ SYBR Gold (Invitrogen, Carlsbad, CA). Images of the gels were obtained under UV light using an EC3 Imager imaging system (UVP, Upland, CA). Sample lanes were analyzed using the Gel Pro Analyzer 3.1 (Media Cybernetics Inc., Silver Spring, MD).

\section{Construction and Sequencing of $16 S$ rRNA Genes Clone Library}

The PCR of bacterial 16S rRNA fragment genes from metagenomic DNA extracted from dairy cows uterine 
fluid was performed using the primers $27 \mathrm{~F} / 1518 \mathrm{R}$ as described previously; PCR was performed in triplicate and pooled before cloning and appropriate controls and blank were included. Amplification products were electrophoresed through a $1.2 \%$ (wt/vol) agarose gel, stained with $0.5 \mu \mathrm{g} / \mathrm{mL}$ ethidium bromide, and visualized under UV light. Positive results were considered to be a pool of amplicons that had the expected molecular size $(\sim 1.5-\mathrm{kb})$. Additionally, concentration and purity were evaluated by optical density using the NanoDrop ND-1000 spectrophotometer (NanoDrop Technologies) at wavelengths of 230,260 , and $280 \mathrm{~nm}$. The PCR products were purified from agarose gel prior cloning using PrepEase Gel Extraction Kit (USB, Affymetrix Inc., Cleveland, $\mathrm{OH}$ ) and cloned into a TA vector using the TOPO TA cloning kit (Invitrogen). Four 16S rRNA gene libraries were constructed.

For cloning purpose, One Shot Chemically Competent Escherichia coli (Invitrogen) cells were transformed with appropriated plasmid concentration, according to the manufacturer's instructions, and grown aerobically overnight on solid Luria-Bertani (LB) media containing kanamycin $(50 \mu \mathrm{g} / \mathrm{mL}) / \mathrm{X}$-gal (5-bromo-4-chloro3 -indolyl- $\beta$-D-galactopyranoside, $80 \mu \mathrm{g} / \mathrm{mL}$; SigmaAldrich) at $37^{\circ} \mathrm{C}$. After overnight incubation, individual white colonies were randomly picked from the plates, placed into $3 \mathrm{~mL}$ of liquid $\mathrm{LB} /$ kanamycin $(50 \mu \mathrm{g} / \mathrm{mL})$, and grown aerobically for 16 to $18 \mathrm{~h}$ at $37^{\circ} \mathrm{C}$. Plasmids of the clones were extracted using the QIAprep Spin Miniprep kit (Qiagen), and the 16S rRNA gene fragments cloned were sequencing using M13 vector primer. All clones containing inserts of the correct size were stored in LB medium containing $20 \%$ (vol/vol) glycerol at $-80^{\circ} \mathrm{C}$.

Generally, only one strand of the DNA fragments was sequenced. This criterion proved sufficient for the taxonomic identification of the cloned 16S rRNA gene fragments obtained using the BLAST (Basic Local Alignment Search Tool; http://blast.ncbi.nlm.nih. gov) search function (Altschul et al., 1990). Both DNA strands were sequenced in cases in which the sequence could not be easily assigned to a particular taxonomic group or in which the quality of the nucleotide sequence could not be clearly determined.

\section{Estimation of the Size of Clone Library and Phylogenetic Analysis}

The resulting electropherograms and sequences were analyzed using GENEIOUS software version 3.0 (Biomatters, Auckland, New Zealand). Chimera formations were identified by using PINTAIL and MALLARD software (http://www.bioinformatics-toolkit.org). Both chimeric sequences and sequences presenting weak signals were excluded from further analysis.

For all statistical analyses, sequences sharing more than $97 \%$ sequence identity were considered as a single phylotype (Vandamme et al., 1996). The clone coverage (C) was calculated according to the following equation: $\mathrm{C}=1-(\mathrm{n} / \mathrm{N})$, where $\mathrm{n}$ is the number of singleton phylotypes, and $\mathrm{N}$ is the total number of clones examined in the $16 \mathrm{~S}$ rDNA clone library. Rarefaction curves (Colwell and Coddington, 1994), Shannon diversity indexes (Gotelli, 2002), and Chao1 richness estimations (Chao and Bunge, 2002) were calculated using ESTIMATES software version 7.5 (http://viceroy.eeb.uconn. edu/EstimateS).

To study the evolutionary relationships among intrauterine bacteria of dairy cows using $16 \mathrm{~S}$ rDNA clone libraries, the sequences obtained were compared with sequences stored in GenBank using the BLAST algorithm (Altschul et al., 1990), and sequences with high similarity were imported to the MEGA4 software (Tamura et al., 2007) and aligned to other $16 \mathrm{~S}$ rRNA gene sequences using ClustalW version 2.0 (http://www.ebi. ac.uk/tools/msa/clustalw2; Larkin et al., 2007). The alignment was further manually corrected, and calculation of the phylogenetic trees was based on these sequence alignments using the neighbor-joining algorithm (Saitou and Nei, 1987). Evolutionary distances were computed using the Jukes-Cantor method (Jukes and Cantor, 1969). To check the robustness of the resulting tree and statistical significance levels of interior nodes, bootstrap analysis with 1,000 replicates was calculated and values above $50 \%$ were reported.

The nucleotide sequence data reported here have been submitted to GenBank under the accession numbers HM754508 to HM754545.

\section{RESULTS}

\section{Bacterial Community Analysis of Uterine Bacteria by DGGE}

Comparison of the bacterial diversity profile present in the uterine samples of healthy and metritic dairy cows using a 2-step nested PCR-DGGE method revealed clear differences in bacterial communities (Figure 1A). The number of bands (i.e., phylotypes or operational taxonomic units, OTU) on the DGGE gel showed a complex profile. The nested PCR approach of using taxon-specific primers in a first PCR followed by the DGGE-PCR with universal bacterial primers not only provided a high-resolution preview of the complexity of the bacterial communities existing but also allowed analysis of minority populations. Gammaproteobacteria exhibited the most complex profile, 
followed by Firmicutes and Bacteroidetes. No OTU was found for Fusobacteria and Actinobacteria from healthy dairy cows in commercial dairy farms 1 and 2, respectively. In general, for all bacterial groups analyzed, the profile was similar when samples from cows presenting the same status were compared. Cluster analysis of the total bacterial community DGGE-profile showed that samples from healthy cows from different dairy farms clustered together, with similarity of approximately $59 \%$ between samples. Samples from metritic cows also clustered in a distinct cluster, with similarity of $56 \%$ between the 2 metritic samples. The 2 distinct clusters showed similarity of $40.5 \%$ between them (Figure 1B). All clustering were supported by high cophenetic correlation coefficients. Alphaproteobacteria and Betaproteobacteria were undetected by PCR-DGGE.

\section{Phylotype Diversity}

In total, 272 clones were screened from the 4 clone libraries. For the healthy status libraries, coverage values were 100 and $97.1 \%$ for commercial dairy farms 1 and 2, respectively. For the libraries related to metritic status, coverage values were 94.5 and $91.3 \%$, respectively, for farms 1 and 2 (Table 2). The results of the rarefaction curves showed that the number of clones screened in the bacterial clone libraries from metritic samples were insufficient to reveal the total number of sequence types within these libraries (Figure 2A). In both cases, the curve showed that a greater number of clones would be necessary to capture all of the sequence types within these libraries to reflect the complete diversity. However, in contrast to those of the metritic status rarefaction curves, the gradients of the healthy status libraries curves were less accentuated and tended to be flat, indicating that these libraries were less diverse and probably more thoroughly sampled, even though the number of clones sequenced was lower (Figure 2A).

A total of approximately 9,15 , and 51 OTU were predicted by the Chao1 nonparametric estimator for the libraries referent to healthy status 1 , metritic status 1 , and metritic status 2, respectively (Table 2). For the clone library referent to healthy status 1 , the estimator could not be calculated because no doubletons were present in the fraction sampled. The values for the Shannon index, a measure of diversity, were higher within libraries whose samples were from commercial dairy farm 2 (Table 2). Unexpectedly, even the diversity index calculated for the healthy status library 2 was higher than the value found for the metritic status library from commercial farm 1 . This result might suggest that the farm environment, even more than the cow status, exerts more influence on richness or evenness in the uterine microbiota.

\section{Composition, Distribution, and Phylogenetic Relationship of the Intrauterine Bacterial Communities}

Partial sequences of about $750 \mathrm{bp}$ were obtained for $27216 \mathrm{~S}$ rRNA clones to identify the predominant bacterial species present in uteri of healthy and metritic postpartum dairy cows. Clone sequences fell into 5 major groups of the Bacteria domain (Gamaproteobacteria, Firmicutes, Fusobacteria, Bacteroidetes, and Tenericutes) according to BLAST searches and phylogenetic analysis. Additionally, one substantial group of uncultured bacteria was observed (Figure 2B). As previously observed in the DGGE profiling, bacterial assemblages, according to clone libraries, are also more similar between samples collected from cows presenting the same status but from different commercial dairy farms.

Phylogenetic analysis revealed that most clones were affiliated with Fusobacteria (47.8\%). Bacteroidetes and Firmicutes were the most diverse groups, presenting 12 different OTU each. Other clones belonged to Tenericutes $(5.9 \%)$ and Proteobacteria (23.2\%). Nearly $67 \%$ of the OTU clustering in the Firmicutes phylum showed low identity with sequences from cultured bacterial sequences but high identity with uncultured bacterial sequences. Other clone sequences showing low identity with sequences from cultured bacteria were grouped in the Bacteroidetes and Fusobacteria clusters (Figure 3). Complete details of all OTU supporting the affiliations in the clone library are listed in Table 3.

Most of the clone sequences from the metritic status libraries (76.7 and $58.3 \%$ of the clones from samples from commercial dairy farms 1 and 2 , respectively) were affiliated with the phylum Fusobacteria (Figure 2B, Table 3), and most of these sequences had high identity ( $\geq 99 \%)$ with Fusobacterium necrophorum and F necrophorum ssp. funduliforme. Several clone sequences were affiliated with the phylum Bacteroidetes (16.4 and 8.7\% of the clones from samples from commercial dairy farms 1 and 2, respectively), and Porphyromonas was the most conspicuous bacterial genus represented in this phylum. Additionally, sequences phylogenetically related to Bacteroides denticanoris, Bacteroides heparinolyticus, Bacteroides suis, Hallella seregens, and Odoribacter denticanis were found. Sequences related to Firmicutes were found in both libraries in minor proportions, and $8.7 \%$ of the sequences from commercial dairy farm 2 library showed identity with the Gammaproteobacteria Hemophilus somnus (Histophilus somni; Table 3). To our knowledge, many of these representatives (see Table 3) have not been observed or reported previously as occurring in metritis or causing the infection. In addition, sequences of some clones in these libraries showed low 
identity with cultured bacteria but high identity with uncultured bacteria (5.5 and $22.8 \%$ of the sequences from the clone libraries 1 and 2, respectively), revealing the presence of uncultured bacteria in the microbial community from metritic uteri.

In the clone libraries from the healthy status groups, differences in the bacterial composition were more accentuated than the assemblage observed for the metritic status libraries. Only sequences affiliated with Gammaproteobacteria were common in both clone libraries. In fact, Gammaproteobacteria was the only group found in the library from dairy farm 1. Approximately 35.1 and $64.9 \%$ showed high identity $(>99 \%)$ with Mannheimia varigena and Pasteurella hemolytica, respectively. Sequences showing high identity with diverse strains of Mannheimia varigena represented $42.9 \%$ of the clone sequences from commercial dairy farm 2 (Figure $2 \mathrm{~B}$, Table 3 ). Additionally, in the library from the second dairy farm, sequences affiliated with Firmicutes (11.4\%) were detected. These sequences showed high identity with sequences of Streptococcus suis and Streptococcus uberis. Further, $45.7 \%$ of the sequences from this clone library were affiliated with the phylum $T e$ nericutes (class Mollicutes), with approximately $23 \%$ of
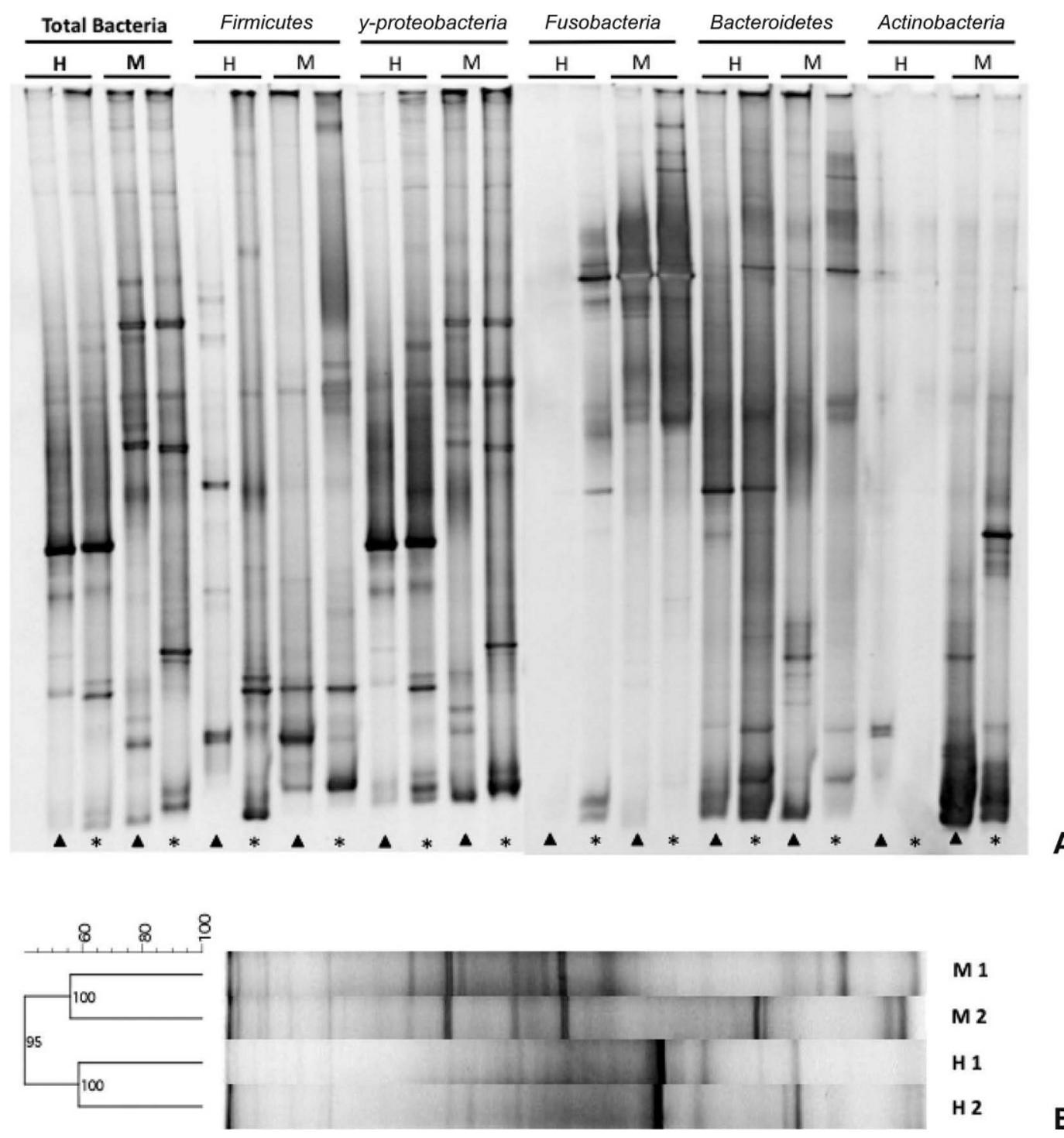

Figure 1. (A) Comparison of total and group-specific bacterial communities present in uteri of healthy $(\mathrm{H} ; \mathrm{n}=5 \mathrm{cows}$ from each farm) and metritic ( $\mathrm{M} ; \mathrm{n}=5$ cows from each farm) Holstein postpartum dairy cows by nested PCR-denaturing gradient gel electrophoresis (DGGE). Commercial dairy farms 1 and 2 are identified with triangles and asterisks, respectively. (B) Dendrogram showing the similarities between mixed samples of uterine fluid from different cow status and dairy farm calculated based on the position and intensity of each DGGE band. The resulting patterns were compared with one another using Dice similarity coefficient, and the matrix was clustered by unweighted pair-group with arithmetic mean (UPGMA) method. Cophenetic correlation coefficients are indicated at branch points of the dendrogram. 
Table 2. Analysis of dairy cows uterine bacterial diversity based on $16 \mathrm{~S}$ ribosomal DNA library information

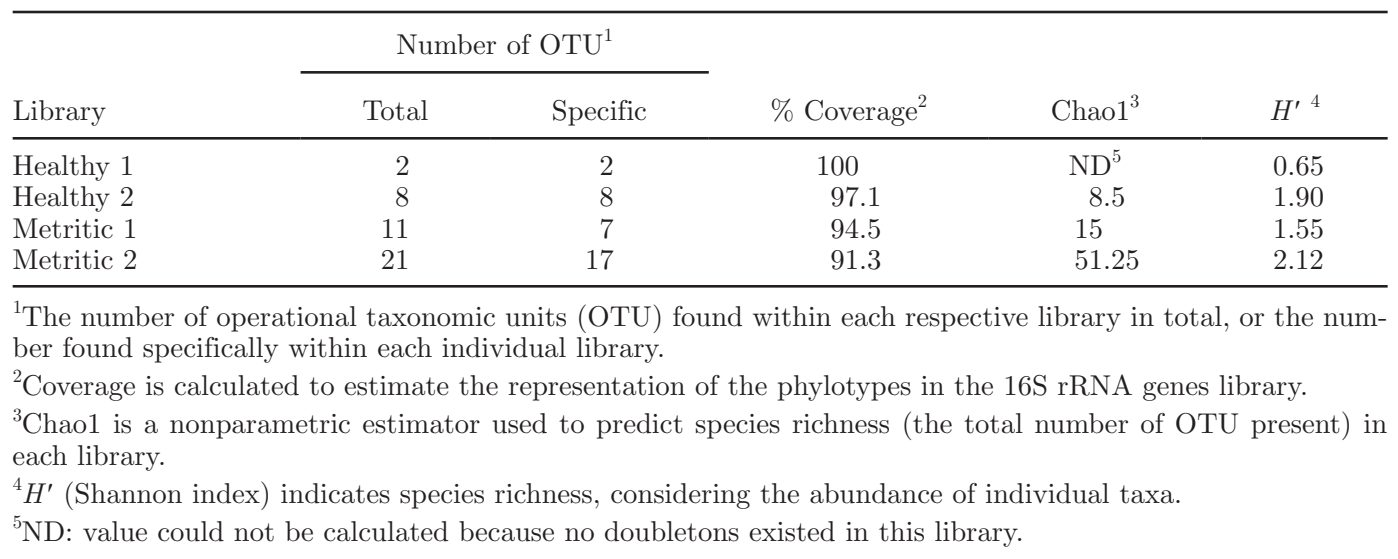

the sequences showing high similarity with Ureaplasma diversum and $23 \%$ with bacteria belonging to the genus Mycoplasma. No clone sequences showing identity with uncultured bacteria were found in either library from healthy status.

\section{DISCUSSION}

Previous studies about metritis-causing pathogens in herds have measured only the cultured portion of the bacterial diversity in uteri after parturition and have shown that this fraction of the microbiota is relatively diverse (Sheldon et al., 2002; Williams et al., 2005; Williams et al., 2007). In the present study, a cultureindependent approach was used to describe and compare the phylogenetic profile of the intrauterine bacterial communities of postpartum dairy cows. A BLAST search of the $16 \mathrm{~S}$ rRNA gene fragments sequences obtained from clone libraries from intrauterine fluid of healthy and metritic cows revealed that 5 known groups and one group belonging to uncultured bacteria were represented in the clone libraries.

Although most clones in the metritic status library belonged to Fusobacteria, Bacteroidetes, and Proteobacteria (particularly Gammaproteobacteria), many clones had sequences that were lowly identical to sequences of known bacteria. We suggest that these sequences belong to groups of bacteria so far uncultured or might represent new bacterial branches not related, or only distantly related, to known cultured microorganisms. A conspicuous number of clones found in these 2 libraries were affiliated with F. necrophorum and Porphyromonas. Both bacteria have been exhaustively isolated from major bovine reproductive infections (Sheldon et al., 2004; Blum et al., 2007) and their presence seemed obvious. Fusobacterium necrophorum ssp. funduliforme is recognized to be highly relevant in the establishment of uterine infection in cattle (Williams et al., 2005; Azawi,
2008) and Porphyromonas levii, an emerging pathogen of human and veterinary importance, has been associated with cases of bovine necrotic vulvovaginitis (Elad et al., 2004). Additionally, sequences found in these 2 libraries were highly similar to sequences of $H$. somnus, Peptostreptococcus anaerobius, and Veillonella parvula, that are primarily known by causing other human and animal syndromes, such as periodontal or respiratory diseases (Aarestrup et al., 2004; Rôças and Siqueira, 2006, 2008).

In the healthy status libraries, most clone sequences were affiliated with $M$. varigena and U. diversum. Although both bacteria are associated with bovine diseases (Doig et al., 1980; Catry et al., 2004), only U. diversum, whose pathogenic mechanisms are not known, has been associated with infection of the upper reproductive tract of cows (Doig et al., 1980) and infertility (Kreplin et al., 1987). The genus Mannheimia is heterogeneous (Angen et al., 1999) and encompasses bacteria with a wide variety of lifestyles. Mannhemia varigena has been isolated in bovine pneumonic lungs, mastitis, and septicemia, and as a common commensal on mucous membranes in the upper respiratory tract and intestinal tract of ruminants (Blackall et al., 2002). Sequences related to other recognized pathogenic bacteria, such as Streptococcus and Mycoplasma, were identified but any sequence related to uncultured bacteria was found in both healthy status libraries.

Specialized literature highlights the importance of $E$. coli and A. pyogenes as critical components in the establishment of metritis (Miller et al., 2007; Sheldon et al., 2010). However, in our study, sequences related to both bacteria were not detected in any library. Escherichia coli are commonly isolated in the early postpartum (first $5 \mathrm{~d}$ postpartum) period and are believed to favor infection by other opportunistic bacteria such as F. necrophorum, A. pyogenes, and Bacteroides sp. (Dohmen et al., 2000; Sheldon et al., 2002). Sampling 
for the present study was performed on d 10 postpartum and, additionally, our metritis case definition was strictly applied to cows that presented all classic clinical signs of metritis as described by Sheldon et al. (2006). Our findings do not diminish the importance of both bacteria because $E$. coli are typically present shortly after calving, whereas $A$. pyogenes are present in the intrauterine environment beyond d 15 following parturition. Further research is needed to evaluate the microbial succession of the intrauterine microbiota from parturition to resumption of uterine infection.

Denaturing gradient gel electrophoresis analysis for profiling of specific bacterial groups showed similarities between samples from cows presenting the same status but from different environment (commercial dairy farms). Additionally, the cluster analysis of the total bacterial community showed that samples from cows with the same status clustered together, regardless of

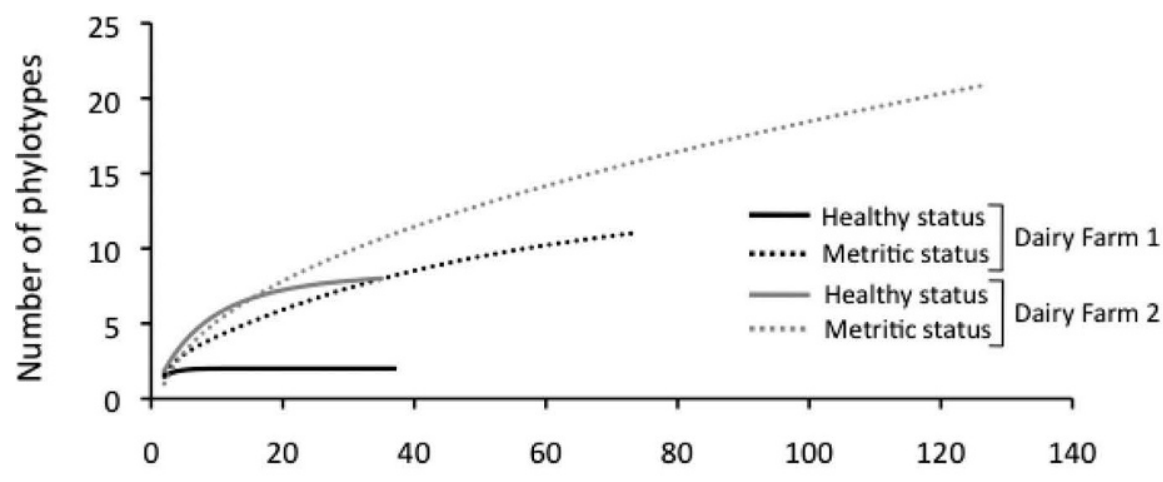

Number of clones screened

A

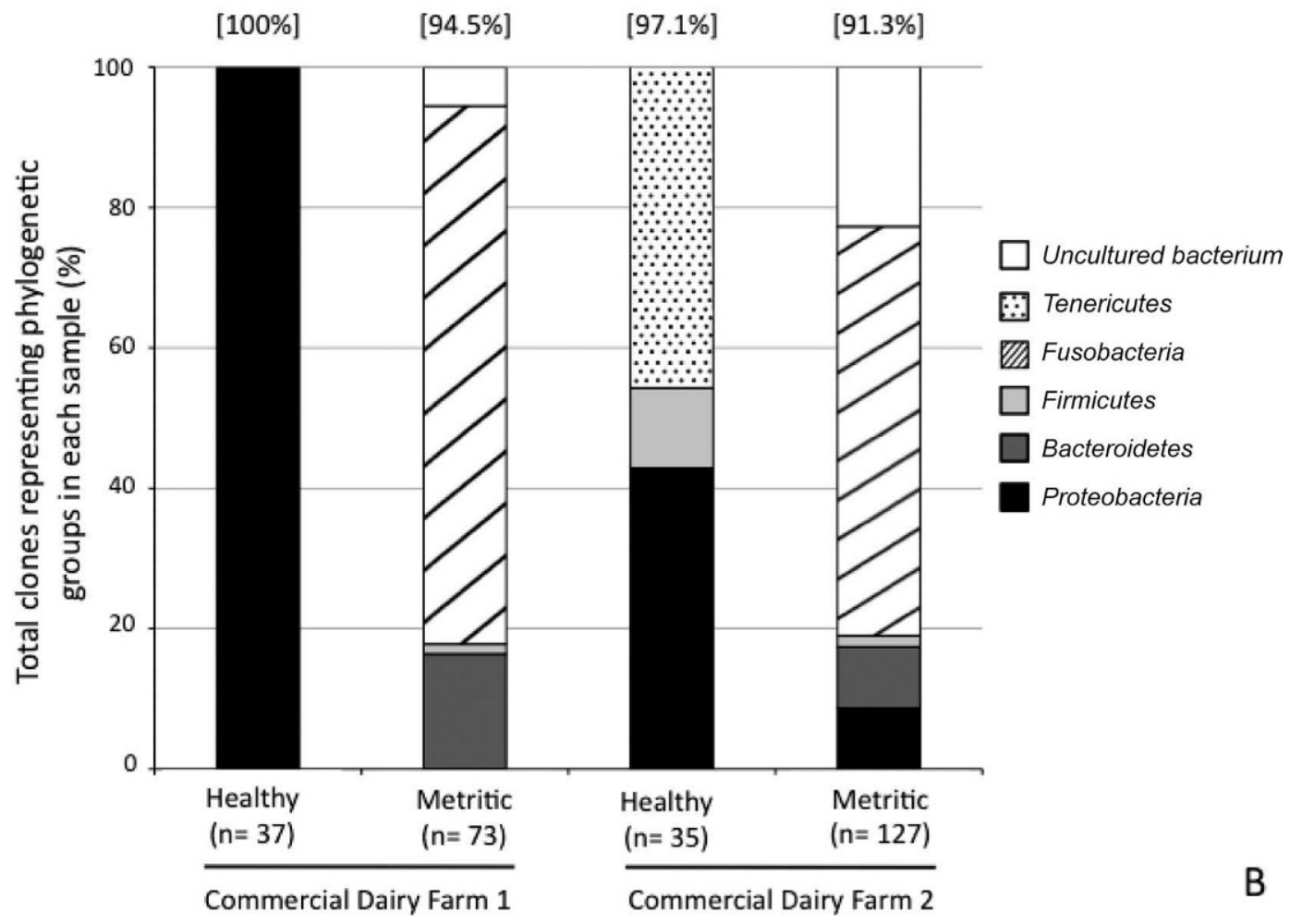

Figure 2. (A) Rarefaction curve indicating the $16 \mathrm{~S}$ rRNA gene diversity within bacterial clone libraries. The frequency of different sequences sharing equal or more than $97 \%$ of identity was plotted as a function of the number of screened clones. (B) Stacked bars showing the bacterial group-level compositions of the uteri of healthy ( 5 cows from each farm) and metritic ( 5 cows from each farm) postpartum dairy cows. Numbers over the bars indicate coverage percentage for each clone library. 
the environment. Because opportunistic and pathogenic bacteria that cause metritis are originally from the farm environment, this fact might be associated with mere similarities in the natural microbiota occurring in the commercial dairy farms where the cows were hosted, or perhaps a minimum microbial core is determinant to define health and disease. The nested approach, which facilitates analysis of minority populations, was chosen

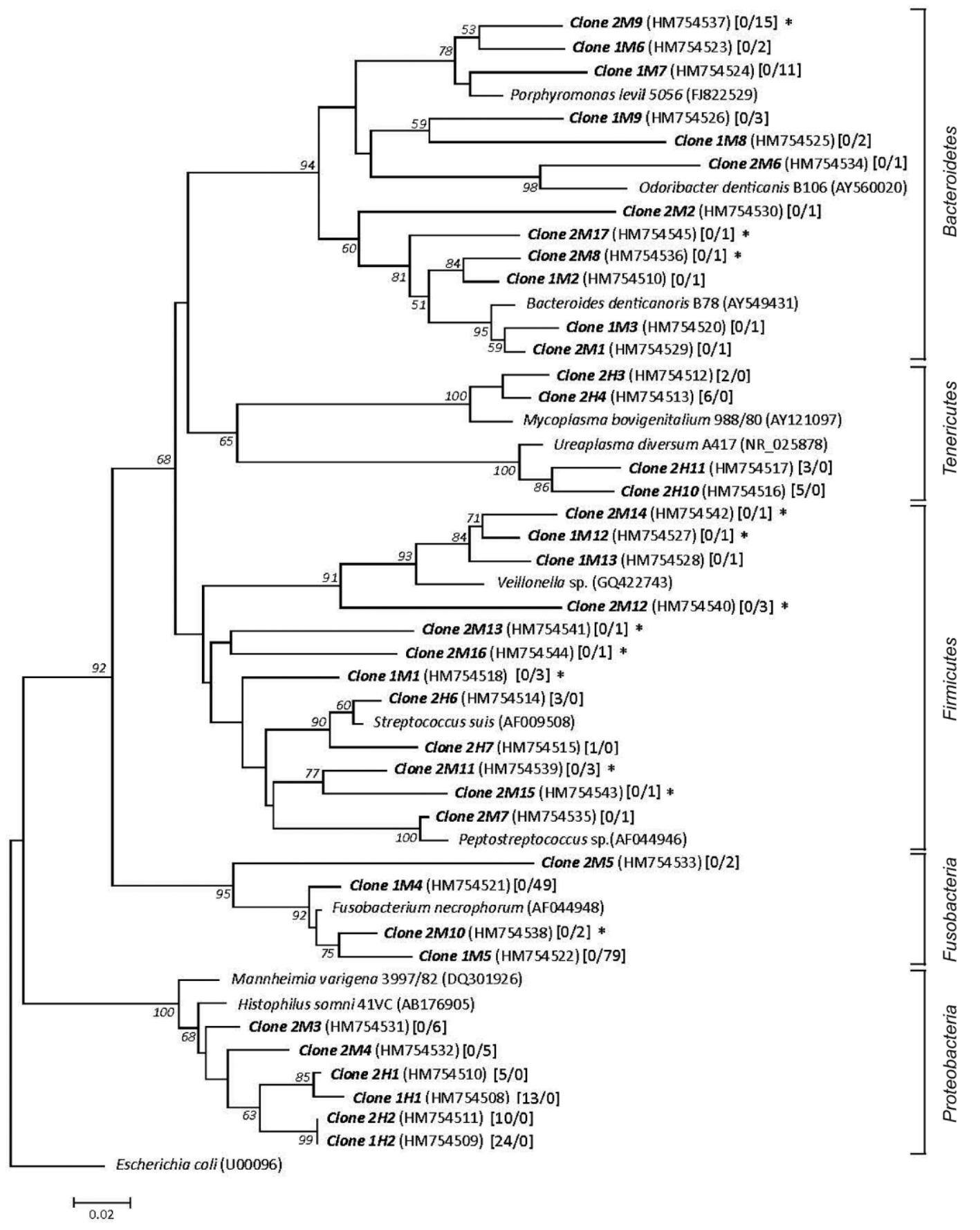

Figure 3. Phylogenetic tree of the bacterial groups identified from clone libraries from uteri of healthy $(\mathrm{n}=10)$ and metritic $(\mathrm{n}=10)$ postpartum Holstein dairy cows showing their affiliations. The evolutionary history was inferred using the neighbor-joining method. The tree is drawn to scale, with branch lengths in the same units as those of the evolutionary distances (computed using the Jukes-Cantor method) used to infer the phylogenetic tree. The scale bar indicates the number of substitutions per site. Escherichia coli served as outgroup. Numbers at the nodes indicate bootstrap values out of 1,000 resamplings (values below 50\% are not shown). GenBank accession numbers are indicated in parentheses. Numbers of clones within each operational taxonomic unit (OTU) identified in the healthy status and metritic status libraries, respectively, are indicated between square brackets [healthy/metritic]. Clones that showed high similarity with uncultured bacteria are marked with an asterisk. 
Table 3. Distribution of $16 \mathrm{~S}$ rRNA gene sequences obtained from bacteria in uteri of healthy and metritic postpartum dairy cows from 2 commercial dairy farms

\begin{tabular}{|c|c|c|c|c|c|c|c|}
\hline \multirow{2}{*}{\multicolumn{2}{|c|}{$\begin{array}{l}\text { Uterine clone } \\
\text { sequence }\end{array}$}} & \multirow[b]{3}{*}{$\begin{array}{c}\text { Sequence } \\
\text { identity (\%) }\end{array}$} & \multirow[b]{3}{*}{ Sequence affiliation ${ }^{1}$ (NCBI accession no.) } & \multicolumn{4}{|c|}{ Clone sequences identified, n ( $\%$ of clones ${ }^{2}$ ) } \\
\hline & & & & \multicolumn{2}{|c|}{ Dairy farm 1} & \multicolumn{2}{|c|}{ Dairy farm 2} \\
\hline $\begin{array}{l}\text { Clone } \\
\text { name }\end{array}$ & $\begin{array}{l}\text { Accession } \\
\text { no. }\end{array}$ & & & Healthy & Metritic & Healthy & Metritic \\
\hline $\begin{array}{l}2 \mathrm{M} 3 \\
2 \mathrm{M} 4 \\
2 \mathrm{H} 1 \\
2 \mathrm{H} 2 \\
1 \mathrm{H} 1 \\
1 \mathrm{H} 2\end{array}$ & $\begin{array}{l}\text { HM754531 } \\
\text { HM754532 } \\
\text { HM754510 } \\
\text { HM754511 } \\
\text { HM754508 } \\
\text { HM754509 }\end{array}$ & $\begin{array}{l}99.9 \\
99.6 \\
97.4 \\
99.1 \\
99.9 \\
99.2\end{array}$ & $\begin{array}{l}\text { Proteobacteria (Gammaproteobacteria) } \\
\text { Hemophilus somnus } 2336 \text { (CP000947) } \\
\text { Histophilus somni }{ }^{3} \text { 41VC (AB176905) } \\
\text { Mannheimia varigena } 177 \text { (NR_024897) } \\
\text { M. varigena } 3997 / 82 \text { (DQ301926) } \\
\text { M. varigena } \mathrm{H} 39 \text { (DQ301927) } \\
\text { Pasteurella hemolytica CCUG } 28148 \text { (AF224287) }\end{array}$ & $\begin{aligned} 37 & (100) \\
0 & (0) \\
0 & (0) \\
0 & (0) \\
0 & (0) \\
13 & (35.1) \\
24 & (64.9)\end{aligned}$ & $\begin{array}{l}0(0) \\
0(0) \\
0(0) \\
0(0) \\
0(0) \\
0(0) \\
0(0)\end{array}$ & $\begin{aligned} 15 & (42.9) \\
0 & (0) \\
0 & (0) \\
5 & (14.3) \\
10 & (28.6) \\
0 & (0) \\
0 & (0)\end{aligned}$ & $\begin{aligned} & 11(8.7) \\
& 6(4.7) \\
& 5(3.9) \\
& 0(0) \\
& 0(0) \\
& \mathbf{0}(\mathbf{0}) \\
& 0(0)\end{aligned}$ \\
\hline $\begin{array}{l}2 \mathrm{M} 1 \\
1 \mathrm{M} 2 \\
1 \mathrm{M} 3 \\
2 \mathrm{M} 2 \\
2 \mathrm{M} 6 \\
1 \mathrm{M} 8 \\
1 \mathrm{M} 9 \\
1 \mathrm{M} 6 \\
1 \mathrm{M} 7\end{array}$ & $\begin{array}{l}\text { HM754529 } \\
\text { HM754519 } \\
\text { HM754520 } \\
\text { HM754530 } \\
\text { HM754534 } \\
\text { HM754525 } \\
\text { HM754526 } \\
\text { HM754523 } \\
\text { HM754524 }\end{array}$ & $\begin{array}{l}99.9 \\
98.1 \\
99.6 \\
89.3 \\
99 \\
99.4 \\
98.8 \\
99.6 \\
99.4\end{array}$ & $\begin{array}{l}\text { Bacteroidetes } \\
\text { Bacteroides denticanoris B78 (AY549431) } \\
\text { Bacteroides heparinolyticus F0110 (GQ422742) } \\
\text { Bacteroides suis DSM 20612 (AB542771) } \\
\text { Hallella seregens (X81877) } \\
\text { Odoribacter denticanis B106 (AY560020) } \\
\text { Porphyromonas sp. 2069 (FJ848564) } \\
\text { Porphyromonas sp. 2070 (FJ848565) } \\
\text { Porphyromonas levii 5056 (FJ822529) } \\
\text { P. levii Israel (GU454798) }\end{array}$ & $\begin{array}{l}0(0) \\
0(0) \\
0(0) \\
0(0) \\
0(0) \\
0(0) \\
0(0) \\
0(0) \\
0(0) \\
0(0)\end{array}$ & $\begin{aligned} 12 & (16.4) \\
0 & (0) \\
1 & (1.4) \\
1 & (1.4) \\
0 & (0) \\
0 & (0) \\
2 & (2.7) \\
3 & (4.1) \\
2 & (2.7) \\
3 & (4.1)\end{aligned}$ & $\begin{array}{l}0(0) \\
0(0) \\
0(0) \\
0(0) \\
0(0) \\
0(0) \\
0(0) \\
0(0) \\
0(0) \\
0(0)\end{array}$ & $\begin{aligned} & 11(8.7) \\
& 1(0.8) \\
& 0(0) \\
& 0(0) \\
& 1(0.8) \\
& 1(0.8) \\
& 0(0) \\
& 0(0) \\
& 0(0) \\
& 8(6.3)\end{aligned}$ \\
\hline $\begin{array}{l}2 \mathrm{M} 7 \\
2 \mathrm{H} 6 \\
2 \mathrm{H} 7 \\
1 \mathrm{M} 13\end{array}$ & $\begin{array}{l}\text { HM754535 } \\
\text { HM754514 } \\
\text { HM754515 } \\
\text { HM754528 }\end{array}$ & $\begin{array}{l}99.7 \\
98.4 \\
99.9 \\
97.9\end{array}$ & $\begin{array}{l}\text { Firmicutes } \\
\text { Peptostreptococcus } \text { sp. S1 (AF044946) } \\
\text { Streptococcus suis (AF009508) } \\
\text { Streptococcus uberis 0140J (AM946015) } \\
\text { Veillonella } \text { sp. F0009 (GQ422743) }\end{array}$ & $\begin{array}{l}0(0) \\
0(0) \\
0(0) \\
0(0) \\
0(0)\end{array}$ & $\begin{array}{l}1(1.4) \\
0(0) \\
0(0) \\
0(0) \\
1(1.4)\end{array}$ & $\begin{array}{l}4(11.4) \\
0(0) \\
3(8.6) \\
1(2.9) \\
0(0)\end{array}$ & $\begin{array}{l}2(1.6) \\
1(0.8) \\
0(0) \\
0(0) \\
1(0.8)\end{array}$ \\
\hline $\begin{array}{l}1 \mathrm{M} 4 \\
1 \mathrm{M} 5 \\
2 \mathrm{M} 5\end{array}$ & $\begin{array}{l}\text { HM754521 } \\
\text { HM754522 } \\
\text { HM754533 }\end{array}$ & $\begin{array}{l}99.7 \\
99.3 \\
97.1\end{array}$ & $\begin{array}{l}\text { Fusobacteria } \\
\text { Fusobacterium necrophorum (AF044948) } \\
\text { F. necrophorum ssp funduliforme JCM3724 (AB525413) } \\
\text { Leptotrichia sp. FB074 (AF385542) }\end{array}$ & $\begin{array}{l}0(0) \\
0(0) \\
0(0) \\
0(0)\end{array}$ & $\begin{aligned} 56 & (76.7) \\
23 & (31.5) \\
33 & (45.2) \\
0 & (0)\end{aligned}$ & $\begin{array}{l}0(0) \\
0(0) \\
0(0) \\
0(0)\end{array}$ & $\begin{aligned} 74 & (58.3) \\
26 & (20.5) \\
46 & (36.2) \\
2 & (1.6)\end{aligned}$ \\
\hline $\begin{array}{l}2 \mathrm{M} 13 \\
2 \mathrm{M} 14 \\
2 \mathrm{M} 15\end{array}$ & $\begin{array}{l}\text { HM754541 } \\
\text { HM754542 } \\
\text { HM754543 }\end{array}$ & $\begin{array}{l}95.3 \\
93.6 \\
95.1\end{array}$ & $\begin{array}{l}\text { (EF559164) } \\
\text { Uncultured bacterium clone ncd564e12c1 (HM278865) } \\
\text { Uncultured bacterium clone RBC4-25 (AB567910) } \\
\text { Uncultured Lachnospiraceae bacterium clone } \\
\text { RF118 (FJ705147) }\end{array}$ & $\begin{array}{l}0(0) \\
0(0) \\
0(0)\end{array}$ & $\begin{array}{l}0(0) \\
0(0) \\
0(0)\end{array}$ & $\begin{array}{l}0(0) \\
0(0) \\
0(0)\end{array}$ & $\begin{array}{l}1(0.8) \\
1(0.8) \\
1(0.8)\end{array}$ \\
\hline $2 \mathrm{M} 16$ & HM754544 & 100 & $\begin{array}{l}\text { Uncultured Oscillospiraceae bacterium clone } \\
\text { XDC12 (FJ938133) }\end{array}$ & $0(0)$ & $0(0)$ & $0(0)$ & $1(0.8)$ \\
\hline $2 \mathrm{M} 17$ & HM754545 & 95.1 & $\begin{array}{l}\text { Uncultured Prevotellaceae bacterium clone } \\
601 \mathrm{~F} \text { (AM420222) }\end{array}$ & $0(0)$ & $0(0)$ & $0(0)$ & $1(0.8)$ \\
\hline
\end{tabular}

${ }^{1}$ Most significant National Center for Biotechnology Information (NCBI) database match.

${ }^{2}$ Values indicated refer to percentage of clones in each library.

${ }^{3}$ Histophilus somni was previously named Hemophilus somnus and has been reclassified based on sequencing of the $16 \mathrm{~S}$ rRNA and rpoB genes (Angen et al., 2003). 
because the final group-specific DGGE pattern could be directly compared (considering that we used the same DGGE conditions) to all the other group-specific patterns obtained, because the same $16 \mathrm{~S}$ rRNA gene fragment was amplified in the second round.

The new insights regarding structure, metabolism, and evolution of uncultured organisms occupying diverse niches brought with the advent of metagenomics (Rondon et al., 2000; Handelsman, 2004) has urged the need to investigate uterine microbiota sidestepping cultural methods. In recent years, this same concept has been used to investigate genetic and functional microbial assemblages in a variety of environments as complex as ocean water (DeLong et al., 2006), soil (Rondon et al., 2000), and human intestine (Turnbaugh et al., 2009). To the best of our knowledge, this article describes the first culture-independent study analyzing the diversity of bacterial populations present in the uteri of healthy and metritic postpartum dairy cows. As we observed, the bacterial assemblages were more similar between samples from cows presenting the same status, regardless of the environment in which the cows were hosted. Although the number of clones screened was insufficient to draw any definitive biological conclusion, it is important to emphasize that the major aim of this study was to investigate differences in the bacterial composition in uteri of postpartum dairy cows and the effect on uterine health by using culture-independent methods.

Our data showed that a profound shift (absolute and relative abundances) occurred in the types of bacteria present in the metritic and healthy groups. We are aware that this work only scratches the surface of the microbial panorama in the dairy cow uterus, but we believe that integrated high-throughput methods would help to reach a consensus and define what constitutes or determine a pathogenic bacterial community in this syndrome. Continuing investigation of the microbial diversity and functionality in this environment will almost certainly reveal complex microbial syntrophies, chemical communication systems among bacteria, and other interactions that will help to explain how microbiota interact in the host's uterus to cause metritis and related reproductive disorders.

\section{CONCLUSIONS}

This study showed that the complexity and assemblage of the intrauterine bacterial community in postpartum dairy cows differed dramatically between healthy cows and cows suffering from metritis. Five known bacterial groups and one group comprising uncultured bacteria were represented in the 16S DNA clone libraries. Fusobacteria was the dominant group in clone libraries from metritic dairy cows and Gammaproteobacteria were more dominant in those libraries from healthy dairy cows.

\section{REFERENCES}

Aarestrup, F. M., A. M. Seyfarth, and O. Angen. 2004. Antimicrobial susceptibility of Haemophilus parasuis and Histophilus somni from pigs and cattle in Denmark. Vet. Microbiol. 101:143-146.

Altschul, S. F., W. Gish, W. Miller, E. W. Myers, and D. J. Lipman. 1990. Basic local alignment search tool. J. Mol. Biol. 215:403410.

Amann, R. I., W. Ludwig, and K. H. Schleifer. 1995. Phylogenetic identification and in situ detection of individual microbial cells without cultivation. Microbiol. Rev. 59:143-169.

Angen, Ø., P. Ahrens, P. Kuhnert, H. Christensen, and R. Mutters. 2003. Proposal of Histophilus somni gen. nov., sp. nov. for the three species incertae sedis 'Haemophilus somnus', 'Haemophilus agni' and 'Histophilus ovis'. Int. J. Syst. Evol. Microbiol. 53:14491456.

Angen, Ø., R. Mutters, D. A. Caugant, J. E. Olsen, and M. Bisgaard. 1999. Taxonomic relationships of the [Pasteurella] haemolytica complex as evaluated by DNA-DNA hybridizations and 16S rRNA sequencing with proposal of Mannheimia haemolytica gen. nov., comb. nov., Mannheimia granulomatis comb. nov., Mannheimia glucosida sp. nov., Mannheimia ruminalis sp. nov. and Mannheimia varigena sp. nov. Int. J. Syst. Bacteriol. 49:67-86.

Azawi, O. I. 2008. Postpartum uterine infection in cattle. Anim. Reprod. Sci. 105:187-208.

Blackall, P. J., M. Bisgaard, and C. P. Stephens. 2002. Phenotypic characterisation of australian sheep and cattle isolates of Mannheimia haemolytica, Mannheimia granulomatis and Mannheimia varigiena. Aust. Vet. J. 80:87-91.

Blackwood, C. B., A. Oaks, and J. S. Buyer. 2005. Phylum- and classspecific PCR primers for general microbial community analysis. Appl. Environ. Microbiol. 71:6193-6198.

Blum, S., M. Mazuz, J. Brenner, O. Friedgut, Y. Stram, O. Koren, T. Goshen, and D. Elad. 2007. Sample-based assessment of the microbial etiology of bovine necrotic vulvovaginitis. Theriogenology 68:290-293.

Breitenstein, A., A. Saano, M. Salkinoja-Salonen, J. R. Andreesen, and U. Lechner. 2001. Analysis of a 2,4,6-trichlorophenol-dehalogenating enrichment culture and isolation of the dehalogenating member Desulfitobacterium frappieri strain TCP-A. Arch. Microbiol. 175:133-142.

Brosius, J., T. J. Dull, D. D. Sleeter, and H. F. Noller. 1981. Gene organization and primary structure of a ribosomal RNA operon from Escherichia coli. J. Mol. Biol. 148:107-127.

Catry, B., G. Opsomer, A. Decostere, B. Feyen, A. de Kruif, and F. Haesebrouck. 2004. Fatal meningitis in a calf caused by Mannheimia varigena. Res. Vet. Sci. 77:187-188.

Chao, A., and J. Bunge. 2002. Estimating the number of species in a stochastic abundance model. Biometrics 58:531-539.

Colwell, R. K., and J. A. Coddington. 1994. Estimating terrestrial biodiversity through extrapolation. Philos. Trans. R. Soc. Lond. B Biol. Sci. 345:101-118.

DeLong, E. F., C. M. Preston, T. Mincer, V. Rich, S. J. Hallam, N. U. Frigaard, A. Martinez, M. B. Sullivan, R. Edwards, B. R. Brito, S. W. Chisholm, and D. M. Karl. 2006. Community genomics among stratified microbial assemblages in the ocean's interior. Science 311:496-503.

Dohmen, M. J., K. Joop, A. Sturk, P. E. Bols, and J. A. Lohuis. 2000. Relationship between intra-uterine bacterial contamination, endotoxin levels and the development of endometritis in postpartum cows with dystocia or retained placenta. Theriogenology 54:1019-1032.

Doig, P. A., H. L. Ruhnke, and N. C. Palmer. 1980. Experimental bovine genital ureaplasmosis. II. Granular vulvitis, endometritis and salpingitis following uterine inoculation. Can. J. Comp. Med. 44:259-266. 
Elad, D., O. Friedgut, N. Alpert, Y. Stram, D. Lahav, D. Tiomkin, M. Avramson, K. Grinberg, and M. Bernstein. 2004. Bovine necrotic vulvovaginitis associated with Porphyromonas levii. Emerg. Infect. Dis. 10:505-507.

Gelsomino, A., and G. Cacco. 2006. Compositional shifts of bacterial groups in a solarized and amended soil as determined by denaturing gradient gel electrophoresis. Plant Soil 38:91-102.

Giovannoni, S. J. 1991. The polymerase chain reaction. Pages 177-201 in Sequencing and Hybridization Techniques in Bacterial Systematics. E. Stackebrandt and M. Goodfellow, ed. John Wiley \& Sons, New York, NY.

Gomes, N. C. M., H. Heuer, J. Schönfeld, R. Costa, L. MendonçaHagler, and K. Smalla. 2001. Bacterial diversity of the rhizosphere of maize (Zea mays) grown in tropical soil studied by temperature gradient gel electrophoresis. Plant Soil 232:167-180.

Gotelli, N. J. 2002. Ecology: Biodiversity in the scales. Nature 419:575-576.

Handelsman, J. 2004. Metagenomics: Application of genomics to uncultured microorganisms. Microbiol. Mol. Biol. Rev. 68:669-685.

Heuer, H., M. Krsek, P. Baker, K. Smalla, and E. M. Wellington. 1997. Analysis of actinomycete communities by specific amplification of genes encoding 16S rRNA and gel-electrophoretic separation in denaturing gradients. Appl. Environ. Microbiol. 63:3233-3241.

Jukes, T. H., and C. R. Cantor. 1969. Evolution of protein molecules. Pages 21-132 in Mammalian Protein Metabolism. Vol. 3. H. N. Munro, ed. Academic Press, New York, NY.

Kreplin, C. M., H. L. Ruhnke, R. B. Miller, and P. A. Doig. 1987. The effect of intrauterine inoculation with Ureaplasma diversum on bovine fertility. Can. J. Vet. Res. 51:440-443.

Larkin, M. A., G. Blackshields, N. P. Brown, R. Chenna, P. A. McGettigan, H. McWilliam, F. Valentin, I. M. Wallace, A. Wilm, R. Lopez, J. D. Thompson, T. J. Gibson, and D. G. Higgins. 2007. Clustal W and Clustal X version 2.0. Bioinformatics 23:29472948.

Miller, A. N., E. J. Williams, K. Sibley, S. Herath, E. A. Lane, J. Fishwick, D. M. Nash, A. N. Rycroft, H. Dobson, C. E. Bryant, and I. M. Sheldon. 2007. The effects of Arcanobacterium pyogenes on endometrial function in vitro, and on uterine and ovarian function in vivo. Theriogenology 68:972-980.

Mühling, M., J. Woolven-Allen, J. C. Murrell, and I. Joint. 2008. Improved group-specific PCR primers for denaturing gradient gel electrophoresis analysis of the genetic diversity of complex microbial communities. ISME J. 2:379-392.

Muyzer, G., E. C. de Waal, and A. G. Uitterlinden. 1993. Profiling of complex microbial populations by denaturing gradient gel electrophoresis analysis of polymerase chain reaction-amplified genes coding for 16S rRNA. Appl. Environ. Microbiol. 59:695-700.

Nübel, U., B. Engelen, A. Felske, J. Snaidr, A. Wieshuber, R. I Amann, W. Ludwig, and H. Backhaus. 1996. Sequence heterogeneities of genes encoding $16 \mathrm{~S}$ rRNAs in Paenibacillus polymyxa detected by temperature gradient gel electrophoresis. J. Bacteriol. 178:5636-5643.

Rôças, I. N., and J. F. Siqueira Jr.. 2006. Culture-independent detection of Eikenella corrodens and Veillonella parvula in primary endodontic infections. J. Endod. 32:509-512.

Rôças, I. N., and J. F. Siqueira Jr.. 2008. Root canal microbiota of teeth with chronic apical periodontitis. J. Clin. Microbiol. 46:3599-3606.
Rondon, M. R., P. R. August, A. D. Bettermann, S. F. Brady, T. H. Grossman, M. R. Liles, K. A. Loiacono, B. A. Lynch, I. A. MacNeil, C. Minor, C. L. Tiong, M. Gilman, M. S. Osburne, J. Clardy, J. Handelsman, and R. M. Goodman. 2000. Cloning the soil metagenome: A strategy for accessing the genetic and functional diversity of uncultured microorganisms. Appl. Environ. Microbiol. $66: 2541-2547$

Saitou, N., and M. Nei. 1987. The neighbor-joining method: A new method for reconstructing phylogenetic trees. Mol. Biol. Evol. 4:406-425.

Sambrook, J., and D. W. Russell. 2001. Molecular Cloning: A Laboratory Manual. 3rd ed. Cold Spring Harbor Laboratory Press, Cold Spring Harbor, NY.

Sheldon, I. M., M. Bushnell, J. Montgomery, and A. N. Rycroft. 2004 Minimum inhibitory concentrations of some antimicrobial drugs against bacteria causing uterine infections in cattle. Vet. Rec. 155:383-387.

Sheldon, I. M., G. S. Lewis, S. LeBlanc, and R. O. Gilbert. 2006 Defining postpartum uterine disease in cattle. Theriogenology 65:1516-1530.

Sheldon, I. M., D. E. Noakes, A. N. Rycroft, D. U. Pfeiffer, and H. Dobson. 2002. Influence of uterine bacterial contamination after parturition on ovarian dominant follicle selection and follicle growth and function in cattle. Reproduction 123:837-845.

Sheldon, I. M., A. N. Rycroft, B. Dogan, M. Craven, J. J. Bromfield, A. Chandler, M. H. Roberts, S. B. Price, R. O. Gilbert, and K. W. Simpson. 2010. Specific strains of Escherichia coli are pathogenic for the endometrium of cattle and cause pelvic inflammatory disease in cattle and mice. PLoS ONE 5:e9192.

Tamura, K., J. Dudley, M. Nei, and S. Kumar. 2007. MEGA4: Molecular evolutionary genetics analysis (MEGA) software version 4.0. Mol. Biol. Evol. 24:1596-1599.

Turnbaugh, P. J., M. Hamady, T. Yatsunenko, B. L. Cantarel, A. Duncan, R. E. Ley, M. L. Sogin, W. J. Jones, B. A. Roe, J. P. Affourtit, M. Egholm, B. Henrissat, A. C. Heath, R. Knight, and J. I. Gordon. 2009. A core gut microbiome in obese and lean twins. Nature 457:480-484.

Vandamme, P., B. Pot, M. Gillis, P. de Vos, K. Kersters, and J. Swings, 1996. Polyphasic taxonomy, a consensus approach to bacterial systematics. Microbiol. Rev. 60:407-438.

Weisburg, W. G., S. M. Barns, D. A. Pelletier, and D. J. Lane. 1991. $16 \mathrm{~S}$ ribosomal DNA amplification for phylogenetic study. J. Bacteriol. 173:697-703.

Whitman, W. B., D. C. Coleman, and W. J. Wiebe. 1998. Prokaryotes: The unseen majority. Proc. Natl. Acad. Sci. USA 95:6578-6583.

Williams, E. J., D. P. Fischer, D. E. Noakes, G. C. England, A. Rycroft, H. Dobson, and I. M. Sheldon. 2007. The relationship between uterine pathogen growth density and ovarian function in the postpartum dairy cow. Theriogenology 68:549-559.

Williams, E. J., D. P. Fischer, D. U. Pfeiffer, G. C. England, D. E. Noakes, H. Dobson, and I. M. Sheldon. 2005. Clinical evaluation of postpartum vaginal mucus reflects uterine bacterial infection and the immune response in cattle. Theriogenology 63:102-117. 